\title{
Patterns of diversity of the north-eastern Atlantic blenniid fish fauna (Pisces: Blenniidae)
}

\author{
VÍTOR C. ALMADA, RUI F. OLIVEIRA, EMANUEL J. GONÇALVES, ARMANDO \\ J. ALMEIDA $\uparrow$, RICARDO S. SANTOS $\ddagger$ and PETER WIRTZ $\$$ Unidade de Investigação em \\ Eco-Etologia, Instituto Superior de Psicologia Aplicada, Rua Jardim do Tabaco 34, 1149-041 Lisboa, \\ Portugal, E-mail: emanuel@ispa.pt $\uparrow$ Laboratório Marítimo da Guia - IMAR, Universidade de Lisboa, \\ Estrada do Guincho, 2750 Cascais, Portugal; and $\$$ Departamento de Oceanografia e Pescas - IMAR, \\ Universidade dos Açores, 9900 Horta, Portugal
}

\begin{abstract}
This paper presents an analysis of the distributional patterns of blenniids (Pisces: Blenniidae) in the north-eastern Atlantic. Two peaks of species diversity were found, both in terms of number of species and number of endemics: one in the tropical African coast and another in the Mediterranean Sea. A cluster analysis of similarity values (Jaccard coefficient) among the eastern Atlantic zoogeographical areas, revealed the following groups: a north temperate group, a tropical group formed by the tropical African coast and Mauritania, another group formed by the islands of Cape Verde, a south temperate group (South Africa), and a southern Atlantic group
\end{abstract}

formed by the islands of Ascension and St Helena. Within the north temperate group, the subgroups with higher similarities were: Azores and Madeira, Canary Islands and Morocco, and the Mediterranean and the Atlantic coast of the Iberian Peninsula. Based on affinity indices, the probable directions of faunal flows were inferred. The tropical coast of Africa and the Mediterranean emerged from this analysis as probable speciation centres of the north-eastern Atlantic blenniid fauna. The Mediterranean may have also acted as a refuge during glacial periods.

Key words Blenniid fishes, distributional patterns, eastern Atlantic, Macaronesia, Mediterranean, speciation centres, species diversity, zoogeography.

\section{INTRODUCTION}

The blennioids have served as models for different scenarios that deal with the evolution and zoogeography of the ichthyofauna of the northeastern Atlantic and the Mediterranean (Zander, 1973, 1980; Wirtz, 1978; Santos et al., 1995).

In a study on the behaviour of Mediterranean tripterygiid fishes, Wirtz (1978) proposed that the three species that currently occur in the Mediterranean may be derived from a common Atlantic ancestor. According to this model, several invasions of the Mediterranean by an Atlantic stock, interspersed with periods of relative isolation, would have promoted speciation and ecological segregation among descendants from previous invasions, leading to a higher level of diversity in the Mediterranean area (Wirtz, 1978).

Zander (1980) emphasized the possible role of the Macaronesian islands (i.e. Azores, Madeira and Canary Islands), especially the Azores, as sites of speciation of eastern Atlantic blennioids, from which the new species would have subsequently migrated to the west European shores.

Santos et al. (1995) emphasized the strong connections between the fish faunas of the Azores, Madeira and Canary Islands. They discussed the possible oceanographic patterns of circulation that may explain the affinities between the faunas of the Macaronesian islands and those of the Mediterranean and the eastern Atlantic shores, despite the prevalence, at least in the Azores, of 
eastward-flowing currents. Similar considerations concerning the marine fauna of the Azores have been presented for other animal groups (e.g. gobiid fishes: Miller, 1984; Rissoidae and Anabathridae molluscs: Gofas, 1990).

In recent years, knowledge of the blenniid faunas of Macaronesia and the West African coast has substantially progressed (Wirtz, 1980, 1994; Dooley et al., 1985; Bath, 1990; Brito, 1991; Santos et al., 1997). Similar improvements have occurred in relation to the shores of the Iberian Peninsula (Nieto \& Alberto, 1990, 1993-94; Oliveira et al., 1992; Almada et al., 1993; Gonçalves et al., 1993).

In this paper, the distributional relationships of the blenniids from the eastern Atlantic and the Mediterranean are analysed, and the different hypotheses on the origin of the blenniid ichthyofauna of the north-eastern Atlantic are re-evaluated.

\section{METHODS}

The division of the main zoogeographic areas of the eastern Atlantic and the Mediterranean shores considered in this study is summarized in Table 1. The database used in the present work (Table 2) was compiled based on this division. The information on the fauna of the Black Sea is also provided for completeness, although it was not subsequently analysed since it is an impoverished subset of the Mediterranean fauna.

Nomenclatural authorities for most species present in Table 2 can be found in Zander (1986) and Bath (1990). The species Parablennius sanguinolentus include populations ascribed to another species (P. parvicornis) by some authors (Zander, 1979; Bath, 1996). Since the populations of the Atlantic islands, namely those of the Azores, are intermediate between those of the Mediterranean and the west coast of Africa (Santos, 1992), it is not yet clear to us if the two species are valid, and the distributional limits of the two morphs are also not yet clearly defined. A species that is referred to in the literature (Lipophrys sabry: Bath, 1982) was not included since it has been shown to be a synonym of L. trigloides (Bath, 1996). Finally, the species Petroscirtes ancylodon was not included since it is a recent immigrant from the Red Sea (Goren \& Galil, 1989).

The Atlantic shore of the Iberian Peninsula was subdivided in more detail than other areas because it was felt that, due to its transitional character, this division would provide a better picture of the relationships between the Mediterranean and the north-eastern Atlantic faunas. Other areas, namely the north-west coast of Africa, should also be further subdivided but the lack of adequate information made this unfeasible.

The similarity among different areas was assessed using a cluster analysis procedure. The Jaccard coefficient of similarity was used and the resulting similarity matrix was analysed through a sequential, agglomerative, hierarchical and nested clustering algorithm described by Sneath \& Sokal (1973). The option used was UPGMA (unweighted pair-group method, arithmetic averages). This option uses a linkage criterion intermediate between the single and the complete ones, in which the decision to include a new element in a cluster is taken with reference to the arithmetic average of the similarity values of the elements already in the cluster. The PC program used was NTSYs version 1.60 (CApplied Biostatistics, Inc.).

To further the analysis of the relationships between areas the following indices $\left(X_{A}\right.$ and $\left.X_{B}\right)$ were computed for each pair of areas (A and $\mathrm{B})$ :

$$
\mathrm{X}_{\mathrm{A}}=\mathrm{A} \cap \mathrm{B} / \mathrm{A} ; \mathrm{X}_{\mathrm{B}}=\mathrm{A} \cap \mathrm{B} / \mathrm{B}
$$

where: $A \cap B$ is the number of species present in both areas, $\mathrm{A}$ is the total number of species present in area $A$, and $B$ is the total number of species present in area B. If, for a given pair of areas, there was a marked flux of fauna in a given direction, we would expect that the target area should present a subset of the species present in the source area rather than the reverse. Thus, an asymmetry between the two indices would be predicted with the smaller value occurring in the source area.

It is important to stress that we are dealing with historical hypotheses that are not necessarily in contradiction with other approaches to the problem of diversity, namely those that relate area and diversity, or energy base and species richness. We are aware that our divisions do not have the same area but, for this type of fish, area is probably not a very relevant issue, since they live in an almost linear band, the shoreline, a few hundred metres wide at most. Our comparisons refer to points located in different geographical 
Table I Definition of the zoogeographic areas considered in the present study and references used for the description of their blenniid fauna

\begin{tabular}{|c|c|c|c|}
\hline Area & $\begin{array}{l}\text { Zoogeographic } \\
\text { region (Briggs, 1974) }\end{array}$ & Area borders & References \\
\hline Boreal & $\begin{array}{l}\text { Eastern Atlantic } \\
\text { region }\end{array}$ & $\begin{array}{l}\text { From the North Sea to the } \\
\text { western entrance of the } \\
\text { English Channel }\end{array}$ & Wheeler, 1969, 1992 \\
\hline Biscay Gulf & $\begin{array}{l}\text { Mediterranean- } \\
\text { Atlantic region }\end{array}$ & $\begin{array}{l}\text { From the western entrance } \\
\text { of the English Channel to Cape } \\
\text { Finisterra (north-west Spain) }\end{array}$ & $\begin{array}{l}\text { Regueiro et al., 1979; } \\
\text { Ibañez \& Motos, 1977; } \\
\text { Motos \& Ibañez, 1979; } \\
\text { Almeida \& Ibañez, 1981; } \\
\text { Ibañez et al., } 1989\end{array}$ \\
\hline $\begin{array}{l}\text { North Iberian } \\
\text { Peninsula }\end{array}$ & $\begin{array}{l}\text { Mediterranean- } \\
\text { Atlantic region }\end{array}$ & $\begin{array}{l}\text { From Cape Finisterra to Cape } \\
\text { Carvoeiro (west Portugal) }\end{array}$ & $\begin{array}{l}\text { Regueiro et al., 1979; Oliveira } \\
\text { et al., 1992; ICN, } 1993\end{array}$ \\
\hline $\begin{array}{l}\text { West Iberian } \\
\text { Peninsula }\end{array}$ & $\begin{array}{l}\text { Mediterranean- } \\
\text { Atlantic region }\end{array}$ & $\begin{array}{l}\text { From Cape Carvoeiro to Cape } \\
\text { S. Vicente (south-west } \\
\text { Portugal) }\end{array}$ & $\begin{array}{l}\text { Oliveira et al., 1992; ICN, } 1993 \\
\text { Nieto \& Alberto, 1990, } \\
\text { 1993-94 }\end{array}$ \\
\hline $\begin{array}{l}\text { South Iberian } \\
\text { Peninsula }\end{array}$ & $\begin{array}{l}\text { Mediterranean- } \\
\text { Atlantic region }\end{array}$ & $\begin{array}{l}\text { From Cape S. Vicente to the } \\
\text { Strait of Gibraltar }\end{array}$ & $\begin{array}{l}\text { Oliveira et al., 1992; } \\
\text { ICN, } 1993\end{array}$ \\
\hline $\begin{array}{l}\text { Western } \\
\text { Mediterranean }\end{array}$ & $\begin{array}{l}\text { Mediterranean- } \\
\text { Atlantic region }\end{array}$ & $\begin{array}{l}\text { From the Strait of Gibraltar to } \\
\text { the Strait of Messina (Sicily) }\end{array}$ & Patzner, 1984 \\
\hline $\begin{array}{l}\text { Central and } \\
\text { Eastern } \\
\text { Mediterranean }\end{array}$ & $\begin{array}{l}\text { Mediterranean- } \\
\text { Atlantic region }\end{array}$ & $\begin{array}{l}\text { From the Strait of Messina to } \\
\text { the eastern limits of the } \\
\text { Mediterranean Sea }\end{array}$ & $\begin{array}{l}\text { Steinitz, 1950; Ben-Tuvia, } \\
\text { 1971; Tortonese, 1975; } \\
\text { Bath, } 1983\end{array}$ \\
\hline Morocco & $\begin{array}{l}\text { Mediterranean- } \\
\text { Atlantic region }\end{array}$ & $\begin{array}{l}\text { From the strait of } \\
\text { Gibraltar to } \\
\text { Cape Juby (Sahara) }\end{array}$ & $\begin{array}{l}\text { Brownell, 1978; Helden \& } \\
\text { Wirtz, 1985; Bath, 1990; } \\
\text { Bath \& Wirtz, } 1992\end{array}$ \\
\hline Mauritania & $\begin{array}{l}\text { Mediterranean- } \\
\text { Atlantic region }\end{array}$ & $\begin{array}{l}\text { From Cape Juby to Cape } \\
\text { Verde (Senegal) }\end{array}$ & $\begin{array}{l}\text { Bath, 1990; Bath \& } \\
\text { Wirtz, } 1992\end{array}$ \\
\hline Tropical Africa & $\begin{array}{l}\text { African tropical } \\
\text { region }\end{array}$ & $\begin{array}{l}\text { From Cape Verde to } \\
\text { Moçamedes (Angola) }\end{array}$ & $\begin{array}{l}\text { Fowler, 1936; Wirtz \& } \\
\text { Bath, 1981; Bath, } 1990\end{array}$ \\
\hline South Africa & $\begin{array}{l}\text { Southern Africa } \\
\text { region }\end{array}$ & $\begin{array}{l}\text { From Moçamedes to the Cape } \\
\text { of Good Hope (South Africa) }\end{array}$ & $\begin{array}{l}\text { Penrith \& Penrith, 1972; } \\
\text { Springer, 1986; Bath, } 1990\end{array}$ \\
\hline Azores Islands & $\begin{array}{l}\text { Mediterranean- } \\
\text { Atlantic region }\end{array}$ & $\begin{array}{l}\text { Islands of Corvo, Flores, Graciosa, } \\
\text { Faial, Pico, S. Jorge, Terceira, } \\
\text { S. Miguel and St Maria }\end{array}$ & $\begin{array}{l}\text { Oliveira et al., 1992; } \\
\text { ICN, 1993; } \\
\text { Santos et al., } 1997\end{array}$ \\
\hline Madeira Islands & $\begin{array}{l}\text { Mediterranean- } \\
\text { Atlantic region }\end{array}$ & $\begin{array}{l}\text { Islands of Madeira and } \\
\text { Porto Santo }\end{array}$ & $\begin{array}{l}\text { Oliveira et al., 1992; } \\
\text { ICN, } 1993\end{array}$ \\
\hline Canary Islands & $\begin{array}{l}\text { Mediterranean- } \\
\text { Atlantic region }\end{array}$ & $\begin{array}{l}\text { Islands of Gran Canaria, } \\
\text { Tenerife, Lanzarote, Gomera } \\
\text { Fuerteventura, La Palma, Hierro }\end{array}$ & $\begin{array}{l}\text { Brito \& Lozano, 1981; } \\
\text { Dooley et al., 1985; } \\
\text { Brito, } 1991\end{array}$ \\
\hline $\begin{array}{l}\text { Cape Verde } \\
\text { Islands }\end{array}$ & $\begin{array}{l}\text { African tropical } \\
\text { region }\end{array}$ & $\begin{array}{l}\text { Islands of S. Antão, } \\
\text { S. Vicente, Boa Vista, } \\
\text { S. Nicolau, Santiago, } \\
\text { Sal, Maio, Fogo and Brava }\end{array}$ & $\begin{array}{l}\text { Fowler, 1936; França \& } \\
\text { Vasconcelos, 1962; Bauchot, } \\
\text { 1966; Wirtz \& Hellinger, } \\
\text { 1987; Wirtz \& Bath, 1989; } \\
\text { Bath, 1989, } 1990\end{array}$ \\
\hline Ascension Island & $\begin{array}{l}\text { African tropical } \\
\text { region }\end{array}$ & Ascension Island & Bauchot, 1966; Bath, 1990 \\
\hline St Helena Island & $\begin{array}{l}\text { African tropical } \\
\text { region }\end{array}$ & St Helena Island & Bauchot, 1966; Bath, 1990 \\
\hline
\end{tabular}


Table 2 Database used in the present study on the distribution of the different blenniid fishes present in the eastern Atlantic and Mediterranean area; $1=$ present; $0=$ absent. AZO = Azores, MAD = Madeira, CAN = Canary islands, CV = Cape Verde, BOR = Boreal, BIS = Biscay Gulf, NIP = north Iberia, $\mathrm{WIP}=$ west Iberia, SIP = south Iberia, $\mathrm{WME}=$ western Mediterranea, EME $=$ central and eastern Mediterranean, BSEA = Black Sea, MOR = Morroco, MAU $=$ Mauritania, TRA $=$ tropical Africa, $\mathrm{SA}=$ south Africa, ASC $=$ Ascension, $\mathrm{SH}=\mathrm{St}$. Helena

Species AZO MAD CAN CV BOR BIS NIP WIP SIP WME EME BSEA MOR MAU TRA SA ASC SH

Aidablennius sphynx Bathyblennius antholops Blennius normani

Blennius ocellaris

Chalaroderma capito Chalaroderma ocelata Coryphoblennius galerita Entomacrodus cadenati Entomacrodus textilis

Hypleurochilus aequipinnis Hypleurochilus bananensis Hypleurochilus langi Lipophrys adriaticus Lipophrys bauchotae Lipophrys caboverdensis Lipophrys canevae Lipophrys dalmatinus Lipophrys nigriceps Lipophrys pholis Lipophrys trigloides Lipophrys velifer Ophioblennius atlanticus Parablennius cornutus Parablennius dialloi

Parablennius gattorugine Parablennius goreensis

Parablennius incognitus

Parablennius pilicornis

Parablennius rouxi

Parablennius ruber

Parablennius salensis

Parablennius sanguinolentus

Parablennius sierraensis

Parablennius tentacularis

Parablennius verryckeni Parablennius zvonimiri

Salaria basilisca

Salaria pavo

$\triangleq \quad$ Scartella caboverdiana Scartella cristata

Scartella nuchifilis

Scartella springeri

Spaniblennius clandestinus Spaniblennius riodourensis

\begin{tabular}{|c|c|c|c|c|c|c|c|c|c|c|c|c|c|c|c|c|c|}
\hline 0 & 0 & 0 & 0 & 0 & 0 & 0 & 0 & 1 & 1 & 1 & 1 & 1 & 0 & 0 & 0 & 0 & 0 \\
\hline 0 & 0 & 0 & 0 & 0 & 0 & 0 & 0 & 0 & 0 & 0 & 0 & 0 & 0 & 1 & 0 & 0 & 0 \\
\hline 0 & 0 & 0 & 0 & 0 & 0 & 0 & 0 & 0 & 0 & 0 & 0 & 0 & 1 & 1 & 0 & 0 & 0 \\
\hline 1 & 0 & 0 & 0 & 1 & 1 & 1 & 1 & 1 & 1 & 1 & 1 & 1 & 0 & 0 & 0 & 0 & 0 \\
\hline 0 & 0 & 0 & 0 & 0 & 0 & 0 & 0 & 0 & 0 & 0 & 0 & 0 & 0 & 0 & 1 & 0 & 0 \\
\hline 1 & 1 & 1 & 0 & 1 & 1 & 1 & 1 & 1 & 1 & 1 & 1 & 1 & 0 & 0 & 0 & 0 & 0 \\
\hline 0 & 0 & 0 & 1 & 0 & 0 & 0 & 0 & 0 & 0 & 0 & 0 & 0 & 0 & 1 & 0 & 0 & 0 \\
\hline 0 & 0 & 0 & 0 & 0 & 0 & 0 & 0 & 1 & 1 & 1 & 0 & 0 & 0 & 1 & 0 & 0 & 0 \\
\hline 0 & 0 & 0 & 0 & 0 & 0 & 0 & 0 & 0 & 0 & 0 & 0 & 0 & 0 & 1 & 0 & 0 & 0 \\
\hline 0 & 0 & 0 & 0 & 0 & 0 & 0 & 0 & 0 & 0 & 1 & 1 & 0 & 0 & 0 & 0 & 0 & 0 \\
\hline 0 & 0 & 0 & 0 & 0 & 0 & 0 & 0 & 0 & 0 & 0 & 0 & 0 & 0 & 1 & 0 & 0 & 0 \\
\hline 0 & 0 & 0 & 1 & 0 & 0 & 0 & 0 & 0 & 0 & 0 & 0 & 0 & 0 & 0 & 0 & 0 & 0 \\
\hline 0 & 0 & 0 & 0 & 0 & 0 & 0 & 1 & 1 & 1 & 1 & 0 & 0 & 0 & 0 & 0 & 0 & 0 \\
\hline 0 & 0 & 0 & 0 & 0 & 0 & 0 & 0 & 1 & 1 & 1 & 0 & 0 & 0 & 0 & 0 & 0 & 0 \\
\hline 0 & 0 & 0 & 0 & 0 & 0 & 0 & 0 & 0 & 0 & 0 & 0 & 0 & 0 & 0 & 1 & 0 & 0 \\
\hline 0 & 0 & 0 & 0 & 0 & 0 & 0 & 0 & 0 & 0 & 0 & 0 & 0 & 0 & 1 & 0 & 0 & 0 \\
\hline 0 & 0 & 1 & 0 & 1 & 1 & 1 & 1 & 1 & 1 & 1 & 0 & 1 & 0 & 0 & 0 & 0 & 0 \\
\hline 0 & 0 & 0 & 0 & 0 & 0 & 0 & 0 & 0 & 0 & 0 & 0 & 0 & 1 & 1 & 0 & 0 & 0 \\
\hline 1 & 1 & 1 & 0 & 0 & 1 & 1 & 1 & 1 & 1 & 1 & 0 & 1 & 0 & 0 & 0 & 0 & 0 \\
\hline 0 & 0 & 1 & 0 & 0 & 1 & 1 & 1 & 1 & 1 & 0 & 0 & 1 & 1 & 1 & 1 & 0 & 0 \\
\hline 0 & 0 & 0 & 0 & 0 & 0 & 0 & 1 & 1 & 1 & 1 & 0 & 0 & 0 & 0 & 0 & 0 & 0 \\
\hline 1 & 1 & 0 & 0 & 0 & 0 & 1 & 1 & 1 & 0 & 0 & 0 & 0 & 0 & 0 & 0 & 0 & 0 \\
\hline 0 & 0 & 0 & 1 & 0 & 0 & 0 & 0 & 0 & 0 & 0 & 0 & 0 & 0 & 0 & 0 & 0 & 0 \\
\hline 1 & 1 & 1 & 1 & 0 & 1 & 1 & 1 & 1 & 1 & 1 & 1 & 1 & 1 & 1 & 0 & 0 & 0 \\
\hline 0 & 0 & 0 & 0 & 0 & 0 & 0 & 0 & 0 & 0 & 0 & 0 & 0 & 0 & 1 & 0 & 0 & 0 \\
\hline 0 & 0 & 0 & 0 & 0 & 0 & 0 & 0 & 0 & 1 & 1 & 1 & 0 & 0 & 0 & 0 & 0 & 0 \\
\hline 0 & 0 & 0 & 0 & 0 & 0 & 0 & 0 & 0 & 0 & 0 & 0 & 0 & 0 & 1 & 0 & 0 & 0 \\
\hline
\end{tabular}


conditions, rather than units of area. On the other hand, when a flux of species from point $A$ to $\mathrm{B}$ is detected this is an historical finding and, if it is due to a richer energy base in A or a greater quantity of shoreline that promoted an increasing diversity in the past, that is a different problem, at another level - causation of historical processes - while our aim is primarily detecting patterns.

\section{RESULTS}

\section{Diversity}

Diversity, as measured by the number of species present in the different areas, is presented in Fig. 1. There is a clear trend for a decrease in the number of species with an increase in latitude, from tropical Africa to the boreal shores of Europe. This finding is in accordance with the distributional patterns of a warm water taxon, as is the case of the blenniids (Springer, 1968, 1993; Nelson, 1994). Two groups depart markedly from this trend: the Mediterranean (both the eastern and the western basins), with a higher number of species than the eastern Atlantic shores of similar latitude; and the Atlantic islands, where the numbers are lower than those for the mainland at similar latitudes.

\section{Endemic species}

Concerning the analysis of the distribution of endemic species, the pattern presented above is
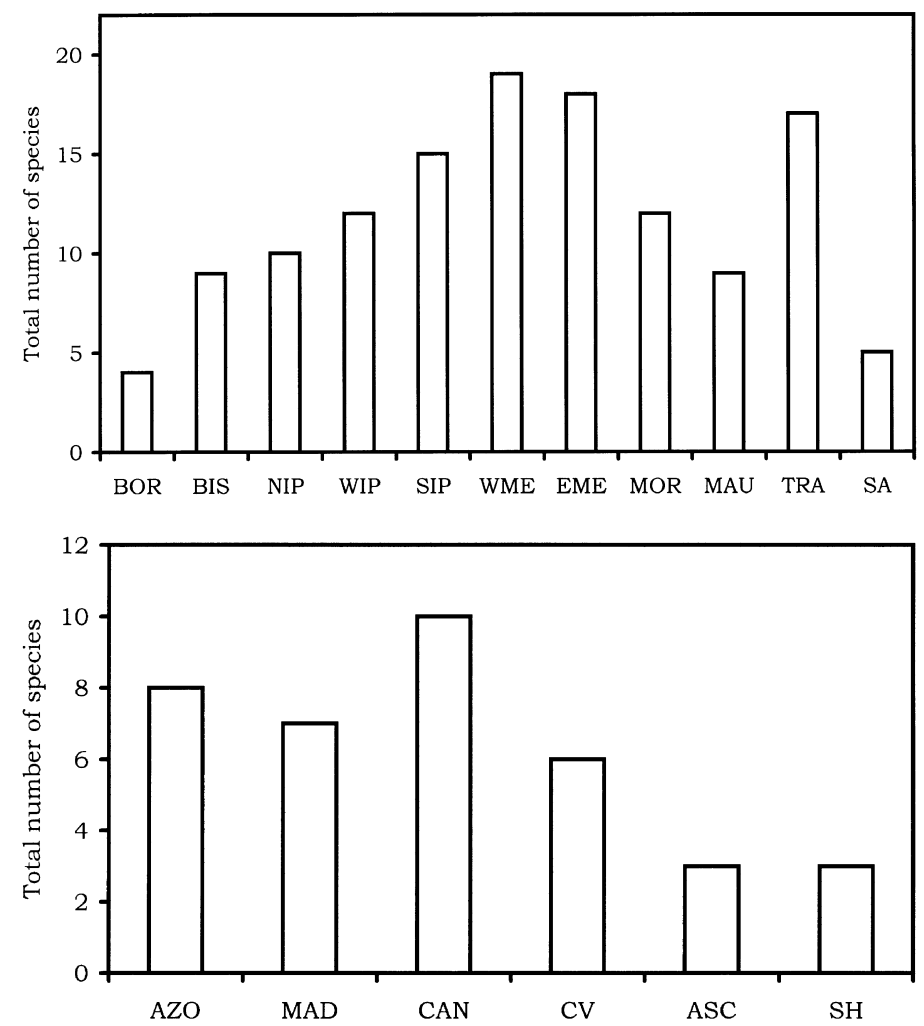

Fig. I Total species richness in blenniid faunas of each of the areas considered in this study: (a) mainland: BOR $=$ boreal, $\mathrm{BIS}=$ Biscay Gulf, NIP $=$ north Iberian Peninsula, WIP $=$ west Iberian Peninsula, SIP = south Iberian Peninsula, WME $=$ western Mediterranean, $\mathrm{EME}=$ central and eastern Mediterranean, MOR $=$ Morocco, $\mathrm{MAU}=$ Mauritania, TRA $=$ tropical Africa, $\mathrm{SA}=$ South Africa; $(\mathrm{b})$ Atlantic islands: AZO = Azores, $\mathrm{MAD}=$ Madeira, $\mathrm{CAN}=$ Canary Islands, $\mathrm{CV}=$ Cape Verde, $\mathrm{ASC}=$ Ascension, $\mathrm{SH}=$ St Helena . The areas are ordered according to decreasing latitude from left to right. 
Table 3 Distribution of endemic Blenniidae species in the eastern Atlantic and Mediterranean biogeographic areas

\begin{tabular}{|c|c|c|}
\hline Area & $n$ & Endemic species \\
\hline Boreal, Biscay, Iberian Peninsula and Macaronesia & 0 & None \\
\hline Mediterranean sea (western and eastern basins) & 5 & $\begin{array}{l}\text { L. adriaticus, L. nigriceps, S. basilisca, } \\
\text { P. tentacularis, P. zvonimiri }\end{array}$ \\
\hline North Africa (Morocco and Mauritania) & 1 & $S$. riodourensis \\
\hline Tropical Africa & 8 & $\begin{array}{l}\text { B. antholops, } H . \text { aequipinnis, } H . \text { langi, } \\
\text { L. bauchotae, } P . \text { dialloi, } P \text {. sierraensis, } \\
\text { P. verryckeni, } S . \text { clandestinus }\end{array}$ \\
\hline Cape Verde Islands & 3 & L. caboverdensis, $P$. salensis, $S$. caboverdiana \\
\hline Ascension and St Helena & 3 & E. textilis, S. nuchifilis, S. springeri \\
\hline
\end{tabular}

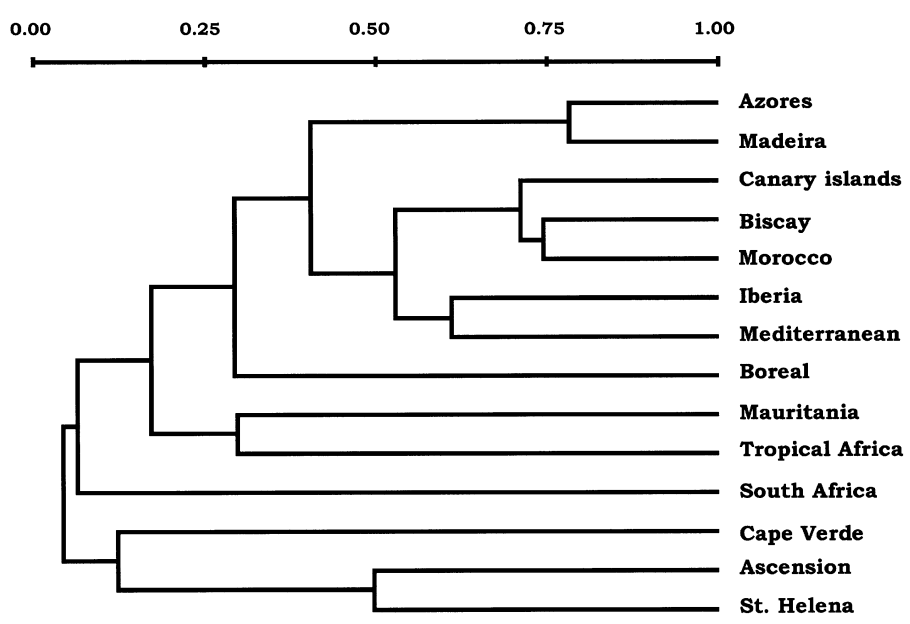

Fig. 2 Dendrogram of the similarities (Jaccard coefficient, UPGMA cluster analysis) of the blenniid fauna among the eastern Atlantic and Mediterranean zoogeographic areas.

further emphasized (Table 3). Two peaks of endemism are found: one in the eastern Atlantic coast of tropical Africa $(N=8)$ and another in the Mediterranean $(N=5)$. Interestingly, these two areas are separated by the Atlantic coast of North Africa (Morocco and Mauritania areas taken together), which contains only one endemic species. Concerning the Atlantic islands, only the tropical groups of Cape Verde, Ascension and St Helena have endemic species. This low level of endemism is also manifested by the absence of endemic species in the islands of S. Tomé (Afonso et al., 1999), in spite of their unquestionable tropical character (Briggs, 1974).

\section{Similarity among areas}

The results of the cluster analysis, performed on the similarity matrix of Jaccard index values for the areas under consideration, reveals that five groups of areas can be recognized in the eastern Atlantic blenniid ichthyofauna (Fig. 2): (i) a temperate group including the Azores, Madeira, Iberian Peninsula, Mediterranean, Canary Islands, Morocco, Biscay and boreal areas; (ii) a tropical group including tropical Africa and Mauritania; (iii) the south temperate area of South Africa; (iv) the islands of Cape Verde; and (v) the islands of Ascension and St Helena. In the temperate 


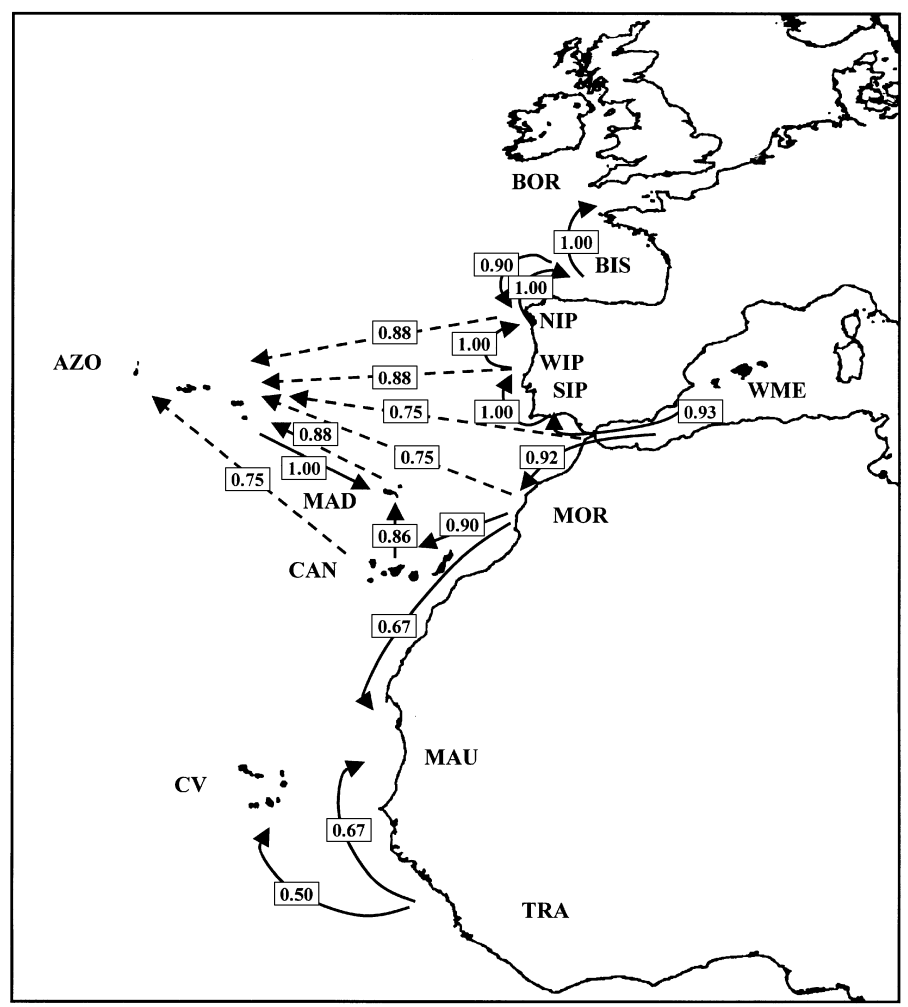

Fig. 3 Probable colonization patterns of blenniid fauna between adjacent zoogeographic areas in the eastern Atlantic and Mediterranean. The arrows represent the probable main flux direction of faunas between adjacent areas. The figures in the boxes represent, for each pair of areas, the higher of the two similarity index values computed for that pair of areas, as described in the methods. This value was used to predict the main direction of colonization between these areas. For abbreviations, see legend to Fig. 1.

group, the affinity of the Azores and Madeira is remarkable (Jaccard index $=77.9 \%$ ), as is the similarity between the Canary Islands and Morocco $(75.0 \%)$. The Mediterranean and the Atlantic coast of the Iberian Peninsula are also closely related $(61.9 \%)$.

To analyse further the relationships between these different areas, two additional affinity indices were computed for each pair of areas (see Methods). The results are summarized in Fig. 3, and confirm the patterns found already for both diversity and endemism. There are two main source areas of blenniid ichthyofauna in the north-eastern Atlantic, one corresponding to the Mediterranean and another to tropical Africa. A faunal movement originating in the Mediterranean seems to have developed northwards from the southern Iberian Peninsula to the boreal region, and southwards to Morocco and Mauritania. The tropical West Africa source seems to have extended northwards to Mauritania, which thus acquires a dual faunistic character.

To investigate the possible origin of the Macaronesian fauna, we have computed these indices between each pair of island groups, and between each island group and the various adjacent mainland areas that could have acted as sources. The computed indices show that the Cape Verde archipelago probably had its main source area in tropical Africa $(50.0 \%)$, while its connections with Mauritania and Morocco are weak (16.7\% in both cases). This relationship between Cape Verde and tropical Africa was not evident in the cluster analysis, possibly because of the high level 
of endemism of Cape Verde, that in the cluster procedure tended to single it out as a separate entity. The Canary Islands had their main source area in the Morocco coast $(90.0 \%)$, with a minor affinity with Mauritania (55.6\%). Madeira is closely related to the Canary Islands $(85.7 \%)$.

The relationship between the Azores and Madeira is remarkable. Both indices for this pair are very high (Madeira-Azores $=100 \%$ and Azores-Madeira $=87.5 \%$ ). It is, however, impossible under this method to determine the potential direction of faunal movement. A similar situation applies to the relationships between the Azores and its possible source areas (other than Madeira): the Canary Islands, Morocco and the Mediterranean (all with $75.0 \%$ ) and the Iberian Peninsula (87.5\%). Indeed, each of these five areas could have influenced the colonization of the Azores archipelago.

One striking feature of the present relationships is that the Cape Verde archipelago shows a very weak relationship with the remaining Macaronesian islands (all with 33.3\%). For this reason, the Cape Verde Islands should not be included in the Macaronesian biogeographic unit, as already pointed out by Wirtz (1994).

Finally, it must be noted that, when high latitudes are considered, the number of species decreases sharply and the dispersion of the family into the boreal region is very weak, being mostly restricted to the British shores (three species). The northern limit for the family is Bergen (Norway - L. pholis).

\section{DISCUSSION}

Two features that deserve special consideration emerged from this study. The levels of diversity and endemism in the Mediterranean Sea and tropical West Africa blenniid fauna, and the patterns of species distribution in the Atlantic islands.

There is a negative relationship between the number of species and latitude, with tropical West Africa as the area of highest diversity and endemism. The occurrence of this maximum of diversity in the tropics is a widespread phenomenon in a broad range of organisms (Briggs, 1974; Wootton, 1990) and thus is not surprising, especially if one considers that blenniids are predominantly distributed in warm waters (Springer,
1968, 1993; Nelson, 1994). In this context, the faunal situation of the Mediterranean is striking, both because it is comparatively rich for its latitude and because it is richer than the adjacent shores of the Atlantic. The presence of several endemic species $(N=5$, which corresponds to $11 \%$ of the total number of Atlantic species) further emphasizes this special character of the Mediterranean fauna. In addition, four more species (A. sphynx, L. dalmatinus, L. canevae and $P$. rouxi), although not being strictly endemic to the Mediterranean, probably evolved there, as they have only spread to the adjacent areas of the Iberian Peninsula and North Africa. Similar findings have been noted by other authors (e.g. Tortonese, 1964; Eckman, 1967; Zander, 1973, 1980; Wirtz, 1978) and have led to the proposal of several models of speciation for Mediterranean blennioids.

In general, these models take into account the desiccation of most of the Mediterranean in the Messinian (6.5 million years ago) (Hsü et al., 1973; Hsü, 1974). This indicates that most blenniid species that currently live in the Mediterranean must have evolved from stocks that colonized this sea from the Atlantic after the Miocene, except probably for the freshwater species Salaria fluviatilis (Zander, 1973). Both Zander (1973) and Wirtz (1978) proposed that the tripterygiids currently living in the Mediterranean may have evolved from a single ancestral stock coming from the Atlantic. Successive waves of immigration interspersed with periods of geographical isolation would have lead to speciation and eco-ethological specialization (Zander \& Heymer, 1970, 1976; Zander, 1973; Wirtz, 1978). Zander (1973) assumed that during the Pleistocene most blennioid species would have been unable to survive in the Mediterranean and that the ancestors of the present forms should have survived in warmer refuges in the western African coast. Zander (1980) also suggested that, for some blenniid lineages, speciation may have taken a different course, with populations colonizing and becoming isolated in the Macaronesian islands and subsequently re-invading the eastern Atlantic and the Mediterranean.

Studies of foraminifera taken from sediments in the Mediterranean floor (Thiede, 1978) indicate that, at least in southern parts of the Mediterranean, the water temperatures during ice 
ages were only a few degrees lower than today. This means that most blenniids that currently live in the northern shores of the Mediterranean may have been able to survive there, rendering the idea of a western African refuge unnecessary.

We suggest that the succession of glaciation episodes, interspersed with periods of high temperatures, probably even higher than today (Thiede, 1978), could provide the mechanism of isolation and re-invasion of the Mediterranean by the same primitive stock that Wirtz (1978) had suggested without detailing the scenario. During interglacial periods it is likely that, at the peaks of the interglacial warming, warm water species could have migrated from the tropics, while during the glacial phases the tropical West Africa and the Mediterranean faunas would have been isolated from each other. This model implies that, apart from a primary speciation centre of high diversity in the tropics, the Mediterranean may have acted as a secondary speciation centre. It would also operate as a refuge for warmtemperate Atlantic species during glaciations.

This would explain the patterns of endemism and diversity found in our data. It must be stressed, however, that the importance of the Mediterranean as a centre of speciation and diversity preservation may have been underestimated, due to the fact that several species that probably evolved or survived there, are presently found in adjacent Atlantic waters, especially those of the Iberian Peninsula. The fall of the sea level during the glaciations and the restriction of warm water to parts of the southern shores could also explain the occurrence of differences, both at the species and subspecies levels, that occur between the eastern and western Mediterranean (Thiede, 1978; Wirtz, 1980). If this scenario proves to be true, a large proportion of the speciation events that led to the present-day Mediterranean and adjacent Atlantic blenniid fauna must be recent and have occurred during the Pleistocene.

Concerning the Macaronesian islands, our results confirm that the icthyofauna of Cape Verde is markedly distinct from the remaining islands and should not be placed in the same entity, as stated above. In addition the Cape Verde Islands, although located near tropical Africa and probably having received their original fauna from there, must have undergone a distinct faunal history for a considerable period of time. Of six blenniid species present in the Cape Verde Islands, three are endemic. This level of endemism is much higher than that of the typical Macaronesian islands. It is clear from our data that the Canary Islands show a high level of similarity with western North Africa, and that the Azores and Madeira possess a blenniid fauna that forms a subgroup of that of the Canary Islands. Despite the fact that predominant currents flow eastwards at the Azores, some authors have provided indications that transport routes operate from Madeira and north-west Africa, carrying organisms, at least sporadically, to the Azores (e.g. Miller, 1984; Gofas, 1990; Santos et al., 1995). It would also be interesting to investigate the possible role of the countless sea mounts present in the north-eastern Atlantic as steppingstones for the colonization of the Macaronesian islands, during glacial periods when the sea level was a hundred metres or more lower than today.

Although the evidence presented in this paper does not exclude a possible migratory route from West Europe to the Azores, at least for some species the colonists must have arrived from Madeira and/or north-west Africa. For instance, the Azorean populations of Parablennius sanguinolentus are intermediate between those of European and Mediterranean shores and those of West Africa, also known as $P$. parvicornis (Arruda, 1979; Zander, 1979; Santos, 1992). Another example is the tropical blenniid Ophioblennius atlanticus that must have been transported from the western to the eastern Atlantic probably at/ or near the tropics, since its closest relative (O. steindachneri) lives along the eastern coasts of the tropical Pacific (Springer, 1962). This species is absent from the Mediterranean and the northern African Atlantic shores and thus must have reached the Azores and Madeira from an African source. It is probably a very recent colonizer of the Azores since it seems that, in the glacial periods, sea temperatures in the archipelago were several degrees lower than today (Corliss, 1975; Lamb, 1977; Crowley, 1981).

If the arguments presented above are correct, then most blenniid fauna of the Azores must be of postglacial origin ( $<12000-15000$ years), which would be consistent with the lack of endemics in Macaronesia (i.e. Azores, Madeira and Canary Islands) (see also Briggs, 1966, 1970; Santos et al., 1995). In this scenario, the model 
of speciation in the Atlantic islands proposed by Zander $(1973,1980)$ is probably not applicable to most blenniids, although it may be feasible for Parablennius ruber, a species with a very atypical distribution, occurring in the Azores and Madeira and the south-west Atlantic coast of Europe (Oliveira et al., 1992).

More work is needed to test further the hypotheses raised by this study. In particular, molecular studies have the potential to evaluate the timing of events presented in this paper, and more detailed phylogenetic studies could identify possible species groups representing distinct lineages of Atlantic ancestors that invaded the Mediterranean and evolved there.

\section{ACKNOWLEDGMENTS}

This study was financially supported by Fundação para a Ciência e a Tecnologia (FCT) through the Plurianual Program (UI \& D 331/94) and through the research projects PBIC/1313/MAR/92 and PRAXIS XXI/3/3.2/EMG/1957/95. The authors would like to thank A.J. dos Santos for valuable help with the statistics, and J.I. Robalo and R.J. Whittaker for help in the final editing of the manuscript.

\section{REFERENCES}

Afonso, P., Porteiro, F.M., Santos, R.S., Barreiros, J.P., Worms, J. \& Wirtz, P. (1999) Coastal marine fishes of São Tomé Island (Gulf of Guinea). Arquipélago - Life and Marine Sciences, 17A, 65-92.

Almada, V.C., Oliveira, R.F., Gonçalves, E.J., Almeida, A.J. \& Barata, E.N. (1993) A new northern limit for the distribution range of Lipophrys canevae (Pisces: Blenniidae) in the Atlantic Ocean. Arquivos Do Museu Bocage - Nova Série, 2, 403-408.

Almeida, A.J. \& Ibañez, M. (1981) Au sujet de la citation de Blennius rouxi Cocco, 1833 sur la coté Basque. Arquivos Do Museu Bocage - Série B, 1, 37-40.

Arruda, L.M. (1979) On the study of a sample of fish captured in the tidal range at Azores. Boletim Da Sociedade Portuguesa de Ciências Naturais, 19, 5-36.

Bath, H. (1982) Lipophrys sabry n. sp. von der Mittelmeerküste Libyens (Pisces: Blenniidae). Senckenbergiana Biologica, 63, 153-160.

Bath, H. (1983) Blenniidae. Check-list of the fishes of the north-eastern Atlantic and of the Mediterranean (ed. by J.C. Hureau and Th. Monod), pp. 519-527. UNESCO, Paris.
Bath, H. (1989) Taxonomie und verbreitung von Parablennius Ribeiro 1915 an der W-Küst Afrikas und den Kapverdischen Inseln mit revalidation von P. verryckeni (Poll 1959) und beschreibung drei neuer arten (Pisces: Blenniidae). Senckenbergiana Biologica, 70, 15-69.

Bath, H. (1990) Blenniidae. Check-list of the fishes of the eastern tropical Atlantic (ed. by J.C. Quéro, J.C. Hureau, C. Karrer, A. Post and L. Saldanha), pp. 905-915. JNICT, Lisboa.

Bath, H. (1996) Beitrag zur Osteologie der Arten der Tribus Parablenniini Die Beziehungen der Knochen des Schädeldaches zum Seitenorgan-System und zu den Weichteilbildungen der Kopfberseite sowie die systematische Bedeutung der Befunde nebst Bemerkungen zu Lupinoblennius dispar Herre 1942. Senckenbergiana Biologica, 76, 65-92.

Bath, H. \& Wirtz, P. (1992) On a collection of blenniid fishes from Mauritania, with a redescription of Spaniblennius riodourensis (Metzelaar, 1919). Zoologische Mededelingen, 66, 265-276.

Bauchot, M.L. (1966) Poissons marins de l'Est Atlantique tropical. V. Blennioidei. Atlantide Report, 9, 63-91.

Ben-Tuvia, A. (1971) Revised list of the Mediterranean fishes of Israel. Israel Journal of Zoology, 20, 1-39.

Briggs, J.C. (1966) Oceanic islands, endemism and marine paleotemperatures. Systematic Zoology, 15, 153-163.

Briggs, J.C. (1970) A faunal history of the north Atlantic Ocean. Systematic Zoology, 19, 19-34.

Briggs, J.C. (1974) Marine zoogeography, McGrawHill, New York.

Brito, A. (1991) Catálogo de los peces de las Islas Canarias. Francisco Lemos Editores, La Laguna.

Brito, A. \& Lozano, G. (1981) El suborden Blennioidei (Pisces, Percomorphi) en las Islas Canarias. Boletin Del Instituto Español de Oceanografia, 6, 8-17.

Brownell, C.L. (1978) Sur quelques collections de poissons littoraux de l'Atlantique Marocain. Bulletin de l'Institut de Pêches Maritimes, 23, 111-133.

Corliss, B.H. (1975) Late Pleistocene paleoclimatology: planktonic foraminiferal analyses of sediment cores from the central North Atlantic. Paleogeography, Paleoclimatology \& Paleoecology, 18, 45-61.

Crowley, T.J. (1981) Temperature and circulation changes in the eastern north Atlantic during the last 150,000 years: evidence from the planktonic foraminiferal record. Marine Micropaleontology, 6, 97-129.

Dooley, J.K., van Tassel, J. \& Brito, A. (1985) An annotated checklist of the shorefishes of the Canary Islands. American Museum Novitates, 2824, $1-49$.

Eckman, S. (1967) Zoogeography of the Sea. Sidgwick \& Jackson, London. 
Fowler, H.W. (1936) The marine fishes of West Africa, based on the collection of the American Museum Congo Expedition 1909-15. Bulletin of the American Museum of Natural History, 70, 1-606.

França, M.L. \& Vasconcelos, M.S. (1962) Peixes do Arquipélago de Cabo Verde. Notas mimeografadas. Centro de Biologia Piscatória, Lisboa, 28, 1-86.

Gofas, S. (1990) The littoral Rissoidae and Anabathridae of São Miguel, Azores. Açoreana Supplement, 97, 1-134.

Gonçalves, E.J., Almada, V.C., Almeida, A.J. \& Oliveira, R.F. (1993) On the occurrence of Parablennius sanguinolentus (Pisces: Blenniidae) on the Portuguese coast. Journal of the Marine Biological Association of the United Kingdom, 73, 465-467.

Goren, M. \& Galil, B. (1989) Petroscirtes ancylodon: first lessepsian migrant blenny in the eastern Mediterranean. Israel Journal of Zoology, 36, 125-128.

Helden, L. \& Wirtz, P. (1985) A comparison of Blennius ocellaris L. 1758, B. riodourensis Metzelaar 1919 and B. normani Poll 1949. Spixiana, 8, $197-217$.

Hsü, K.J. (1974) The Miocene dessication of the Mediterranean and its climatical and zoogeographical implications. Naturwissenschaften, 61, 137-142.

Hsü, K.J., Ryan, W.B.F. \& Cita, M.B. (1973) Late Miocene desiccation of the Mediterranean. Nature, 242, 240-244.

Ibañez, M. \& Motos, L. (1977) Blennius ponticus (Slastenenko, 1934) nueva especie para la fauna Atlantica. Vie et Milieu, 27, 377-383.

Ibañez, M., San Mill, M.D. \& Ripa, M.I. (1989) Intertidal ichthyofauna of the Spanish Atlantic coast. Scientia Marina, 53, 451-455.

ICN (1993) Livro Vermelho dos Vertebrados de Portugal, 3 - Peixes Marinhos E Estuarinos. Instituto da Conservação da Natureza, Lisboa.

Lamb, H.H. (1977) Climate: present, past and future, vol. 2 - Climatic History and the future. Methuen, London.

Miller, P.J. (1984) The gobiid fishes of temperate Macaronesia (eastern Atlantic). Journal of Zoology, 204, 363-412.

Motos, L. \& Ibañez, M. (1979) Contribucion al estudio de los blenideos de la costa Vasca. Primer Simposio de Bentos, San Sebastian, pp. 215-222.

Nelson, J.S. (1994) Fishes of the world, 3rd edn. John Wiley and Sons, New York.

Nieto, P. \& Alberto, L.J. (1990) Hypleurochilus bananensis (Poll, 1959) (Blenniidae). New record for the European Atlantic coast and for the Spanish fauna. Cybium, 14, 361-364.

Nieto, P. \& Alberto, L.J. (1993-94) Gobiidae y Blenniidae de la zona intermareal de la costa suroccidental de Andalucía (Espanã). Miscelanea Zoologica, 17, 179-188.

Oliveira, R.F., Almada, V.C., Almeida, A.J., Santos, R.S. \& Gonçalves, E.J. (1992) A checklist of the
Blennioid fishes (Teleostei, Blennioidei) occurring in Portuguese waters. Arquipélago — Life and Earth Sciences, 10, 23-37.

Patzner, R.A. (1984) Die Blenniiden von Ibiza (Balearen) und ihre Verbreitung im West-Mittelmeer. Senckenbergiana Biologica, 65, 179-203.

Penrith, M.J. \& Penrith, M.L. (1972) The Blenniidae of western southern Africa. Cimbebasia - Serie A, 2, 65-90.

Regueiro, S.D., Alvarez, J.C.P. \& Solórzano, M.R. (1979) Contribuicion al estudio de los blenidos del litoral Gallego (Pisces: Blenniidae). Brama, 3, 55-73.

Santos, R.S. (1992) Behavioural ecology, phenology and ethology of an intertidal blenny Parablennius sanguinolentus parvicornis (Valenciennes in Cuvier \& Valenciennes 1836) (Pisces: Blenniidae) from the Azores. PhD Thesis, University of Liverpool.

Santos, R.S., Hawkins, S., Monteiro, L.R., Alves, M. \& Isidro, E.J. (1995) Marine research, resources and conservation in the Azores. Aquatic Conservation: Marine and Freshwater Ecosystems, 5, 311-354.

Santos, R.S., Porteiro, F.M. \& Barreiros, J.P. (1997) Marine fishes of the Azores: an annotated checklist and bibliography. Arquipelago - Life and Marine Sciences Supplement, 1, 1-244.

Sneath, P.H.A. \& Sokal, R.R. (1973) Numerical taxonomy. W.H. Freeman, San Francisco.

Springer, V.G. (1962) A review of the blenniid fishes of the genus Ophioblennius Gill. Copeia, 1962, 426-433.

Springer, V.G. (1968) Osteology and classification of the fishes of the family Blenniidae. Bulletin of the United States National Museum, 284, 1-83.

Springer, V.G. (1986) Blenniidae. Smiths' sea fishes (ed. by M.M. Smith and P.C. Heemstra), pp. 742755. Springer-Verlag, Berlin.

Springer, V.G. (1993) Definition of the suborder Blennioidei and its included families (Pisces: Perciformes). Bulletin of Marine Science, 52, 472-495.

Steinitz, H. (1950) Contribution to the knowledge of the Blenniidae of the eastern Mediterranean III. Reviews of the Faculty of Sciences of the University of Istanbul B, 15, 60-87.

Thiede, J. (1978) A glacial Mediterranean. Nature, 276, 680-683.

Tortonese, E. (1964) The main biogeographical features and problems of the Mediterranean fish fauna. Copeia, 1964, 98-107.

Tortonese, E. (1975) Fauna d'Italia. Osteichthyes (Pesci, Ossei), Parte Seconda. Editores Calderini, Bologna.

Wheeler, A. (1969) The fishes of the British Isles and north-west Europe. MacMillan, London.

Wheeler, A. (1992) A list of common and scientific names of fishes of the British isles. Journal of Fish Biology, 41 (Suppl. A), 1-37.

Wirtz, P. (1978) The behaviour of the Mediterranean Tripterygion species (Pisces, Blennioidei). Zeitschrift für Tierpsychologie, 48, 142-174. 
Wirtz, P. (1980) A revision of the eastern-Atlantic Tripterygiidae (Pisces, Blennioidei) and notes on some West African blennioid fish. Cybium, 3e Serie, 11, 83-101.

Wirtz, P. (1994) Underwater guide Madeira, Canary Islands, Azores — Fish. Verlag Stephanie Naglschmid, Stuttgart.

Wirtz, P. \& Bath, H. (1981) Lipophrys bauchotae n. sp. from the eastern tropical Atlantic (Pisces: Blenniidae). Senckenbergiana Biologica, 62, 225-232.

Wirtz, P. \& Bath, H. (1989) Lipophrys caboverdensis n. sp. from the Cape Verde Islands (Pisces: Blenniidae). Senckenbergiana Biologica, 69, 15-27.

Wirtz, P. \& Hellinger, J. (1987) Zur Zoogeographie der Atlanto-mediterranen Blennioidea mit besonderer Berücksichtigung der Kapverdischen Inseln (Vertebrata: Pisces). Courier Forschungsinstitut Senckenberg, 95, 99-102.

Wootton, R.J. (1990) Ecology of Teleost fishes. Chapman \& Hall, London.

Zander, C.D. (1973) Evolution of Blennioidei in the Mediterranean sea. Revue Travaux de L'Institut de Péches Maritimes, 37, 215-221.

Zander, C.D. (1979) Morphologische und ökolo- gische Untersuchung der Schleimfische Parablennius sanguinolentus (Pallas, 1811) und P. parvicornis (Valenciennes, 1836) (Perciformes, Blenniidae). Mitteilungen Aus Dem Hamburgischen Zoologischen Museum und Institut, 76, 469-474.

Zander, C.D. (1980) Zoogeography and speciation of Mediterranean blennioids. Journées de Etudes Systématiques et Biogéographiques de Mediterraneen, CIESM, Cagliari, 13-38.

Zander, C.D. (1986) Blenniidae. Fishes of the NorthEastern Atlantic and the Mediterranean (ed. by P.J.P. Whitehead, M.-L. Bauchot, J.-C. Hureau, J. Nielsen and E.E. Tortonese), pp. 1096-1112. UNESCO, Paris.

Zander, C.D. \& Heymer, A. (1970) Tripterygion tripteronotus Risso 1810 und Tripterygion xanthosoma n. sp., eine ökologische Speziation. Vie et Milieu, 21, 363-394.

Zander, C.D. \& Heymer, A. (1976) Morphologische und ökologische Untersuchungen an den speleophilen Schleimfischartigen Tripterygion melanurus Guichenot 1850 und T. minor Kolombatovic 1892. Zeitschrift für Zoologische Systematik und Evolutionsforschung, 14, 41-59. 